\title{
Serum activity of creatine kinase and aminotransferase aspartate enzymes of horses submitted to muscle biopsy and incremental jump test
}

\author{
Atividade sérica das enzimas creatina quinase e aspartato aminotransferase de equinos \\ submetidos à biópsia muscular e teste incremental de salto
}

\author{
SOARES, Otavio Augusto Brioschi ${ }^{1,2} *$; D'ANGELIS, Flora Helena de Freitas ${ }^{1}$; \\ FERINGER JÚNIOR, Walter Heinz ${ }^{1}$; NARDI, Kamirro Bacciotti ${ }^{1}$; TRIGO, Pablo ${ }^{3}$; \\ ALMEIDA, Fernando Queiroz de ${ }^{3}$; MIRANDA, Ana Cláudia Tavares ${ }^{3}$; QUEIROZ- \\ NETO, Antonio ; FERRAZ, Guilherme de Camargo ${ }^{1}$
}

\footnotetext{
${ }^{1}$ Universidade Estadual Paulista, Faculdade de Ciências Agrárias e Veterinárias, Departamento de Morfologia e Fisiologia Animal, Jaboticabal, São Paulo, Brasil.

${ }^{2}$ Exército Brasileiro, Academia Militar das Agulhas Negras, Hospital Veterinário, Resende, Rio de Janeiro, Brasil.

${ }^{3}$ Universidade Federal Rural do Rio de Janeiro, Instituto de Veterinária, Laboratório do Desempenho Equino, Seropédica, Rio de Janeiro, Brasil.

*Endereço para correspondência: tenveguausto@yahoo.com.br
}

\section{SUMMARY}

The objective was to evaluate serum activity of the enzymes creatine kinase (CK) and aspartate aminotransferase (AST), which are leakage enzymes responsive to muscle injury, of athletic horses that underwent muscle biopsy and incremental jump test (IJT) involving incremental jumps. The animals were grouped as follows: the first group, horses with history of superior performance (SP); the second, with a history of inferior performance (IP); and lastly, a control group (CG). All groups underwent biopsy of the gluteus medius muscle, while groups SP and IP were also submitted to the incremental jump test (IJT) 24 hours after biopsy. The IJT consisted of three stages with 40 jumps each, where jump height increased progressively, from 40 to 60 and last, $80 \mathrm{~cm}$. Blood samples were drawn before biopsy, and 6 and 24 hours after the exercise as well. The levels of CK serum activity increased 6 hours after exercise and decreased 24 hours later in all groups, including CG. AST activity did not increase after biopsy and exercise. There was no increase of both enzyme activities that could be attributed to the exercise, possibly due to exercise short duration and/or low intensity. We conclude that the muscle biopsy was able to show that there was enough stimulus to cause CK enzyme leakage into the plasma, and consequent detection of increased serum activity, while the incremental jump test did not.

Keywords: equine, equestrian, muscle enzymes, show jumping, performance test

\section{RESUMO}

Objetivou-se avaliar a atividade sérica das enzimas creatina quinase (CK) e aspartato aminotransferase (AST), enzimas de extravazamento responsivas à lesão muscular, de equinos de salto submetidos à biópsia muscular e a um teste de exercício padronizado, envolvendo saltos incrementais. Foram utilizados três grupos de animais, um com histórico de desempenho superior (SP), um com histórico inferior (IP) e um grupo controle (CG). Todos os grupos foram submetidos à biópsia muscular no gluteus medius e somente os grupos SP e IP ao teste de saltos incrementais (IJT), 24h após a biópsia. O IJT foi constituído de três estágios de alturas progressivas, com 40 saltos cada, nas alturas de 40,60 e $80 \mathrm{~cm}$. Amostras de sangue foram coletadas antes da biópsia, $6 \mathrm{~h}$ e $24 \mathrm{~h}$ após o exercício. Os níveis de atividade sérica da CK elevaram-se 6h e diminuíram $24 \mathrm{~h}$ após o exercício em todos os grupos, inclusive no CG. A atividade da AST 
não demonstrou aumento após a realização da biópsia e do exercício. Não foi visto aumento da atividade de ambas enzimas mensuradas que pudesse ser atribuído ao exercício, possivelmente pela baixa duração e/ou intensidade do mesmo. Conclui-se que a biópsia muscular caracterizou estímulo suficiente para haver extravasamento somente da enzima muscular CK para o plasma, e consequente detecção de aumento de sua atividade sérica, enquanto o teste de exercício padronizado realizado não.

Palavras-chave: enzimas musculares, equinos, hipismo, salto, teste de desempenho

\section{INTRODUCTION}

One of the organs affected by exercise is logically the muscle, which suffers micro-damage due to effort employed load. These lesions can be measured in the laboratory by determining the serum activity of few muscle enzymes such as creatine kinase (CK), aspartate aminotransferase (AST) and lactate dehydrogenase (LDH) (OVERGAARD et al., 2004).

This activity has been studied by several authors before and after exercise and can be used to detect muscle diseases (BOFFI et al., 2007), characterization of exercise intensity (ART et al., 1990; TEIXEIRA-NETO et al., 2008; FERRAZ et al., 2010) and predicting possible complications that can arise from the exercise (TRIGO et al., 2010). The CK enzyme has the function of phosphorylation of creatine and actively participates in energy metabolism of various tissues, including muscle tissue. After exercise or muscle injury, it is rapidly released into the bloodstream and its activity peaks 4-12 hours later (KINGSTON, 2008). On the other hand, the AST enzyme function is the deamination of aspartate to oxaloacetate, while its slower release causes peaking activity about 24 hours after stimulation stress (TEIXEIRANETO et al., 2008). The muscle enzyme activity is normally low in the plasma, since they are within the myocyte; however, after exercise or muscle injury this scenario changes. This activity significantly rises within minutes or hours due to increased cellular permeability, cell necrosis, deficient elimination or increased enzymatic synthesis (MACLEAY, 2009).

Muscle biopsy in horses, a technique classically used to detect muscle injuries, has been used to understand the physiology of exercise and to monitor training (D'ANGELIS et al., 2008).

Although several studies measure the activity of serum enzymes before and after exercises, there are few studies that investigate the activity of these enzymes after muscle biopsy, in order to quantify the magnitude or severity of the injury.

Therefore, the objective of the present work was to evaluate the serum activities of CK and AST of athletic jumping horses before and after muscle biopsy and incremental jump test as well.

\section{MATERIAL AND METHODS}

We used 21 Brazilian Sport horses, male and female, aged $11.6 \pm 3.1$ years old, weighing average $490.2 \pm 53.7 \mathrm{Kg}$, and $1.59 \pm 0.09 \mathrm{~m}$ tall. They were all jumping horses that belong to the Brazilian Army and were kept stalled in Academia Militar das Agulhas Negras, Resende - RJ. Daily nutritional management consisted of roughage supplied ad libitum and commercial concentrate at the amount of $1 \%$ body weight. The horses underwent a thorough clinical examination, as well as hematological and biochemical tests 
to ensure they were healthy and could, therefore, take part in the trial.

Four professional riders participated in the tests, all graduated latu sensu as riding instructors, from the Escola de Equitação do Exército, Rio de Janeiro RJ. The riders were between 1.75 and $1.83 \mathrm{~m}$ tall, weighed between 75 and $83 \mathrm{Kg}$ and were randomly distributed in the jumping groups.

The animals were distributed in three groups, two of which underwent the biopsy and the exercise test; the first group, horses with a history of superior performance (SP, $\mathrm{n}=8)$ and the second, horses with inferior performance (IP, $\mathrm{n}=$ 8 ), and last, the control group ( $\mathrm{GC}, \mathrm{n}=$ $5)$, which underwent only muscle biopsy. The horses with a history of participation in amateur events only, riding school level, with maximum height obstacles of $1.00 \mathrm{~m}$, were classified as lower performance (IP). While the horses with history of participation in senior events during the year before, levels CSN and CSN 1*, with maximum height obstacles of 1.10 and $1.20 \mathrm{~m}$, were classified as superior performance (SP) - (CBH, 2012).

All horses were submitted to gluteus medius muscle biopsy 24 hours before the exercise test, according to procedure described by D'Angelis et al. (2007), in order to isolate the effect of manipulation and muscle injury resulting from the biopsy as opposed to the one arising from the exercise.

The exercise test, called incremental jump test (IJT) was proposed in order to study the use of specific muscle groups during horse jumping. This test aims to assess as much as possible the fitness for jumping exercise alone.

The IJT was conducted in a covered sandy arena with 10 obstacles arranged in two rows that covered a total distance of 74 meters, according to the photograph shown in Figure 1.

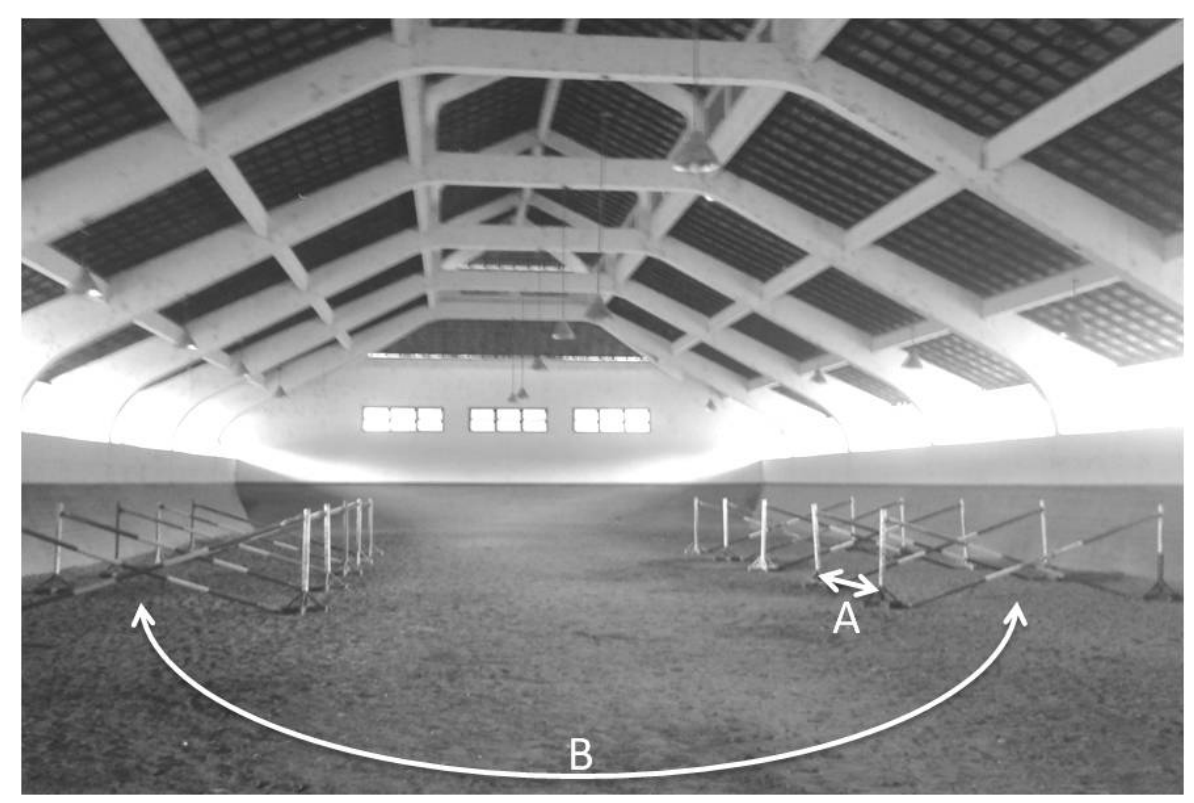

Figure 1. Photograph showing the track in the covered sandy arena used for the incremental jump tests (IJT). The distance between the vertical obstacles was $3 \mathrm{~m}$ (letter A) and the distance of each curve was $25 \mathrm{~m}$ (letter B), totaling $74 \mathrm{~m}$. 
Before the test, a 10-minute warm up consisting of walk and trot was performed. The exercise incremental jump test consisted of three stages with the simple vertical obstacles set at increasing heights of 40,60 and $80 \mathrm{~cm}$. During each stage the horse had to clear four times the course at constant speed of $300 \mathrm{~m} / \mathrm{min}$, and a three-minute interval between them.

Blood was drawn via jugular venipuncture before, 6 and 24 hours after the exercise. The blood was stored in tubes with negative pressure without anticoagulant, centrifuged and separated for subsequent colorimetric measurement of creatine kinase (CK) and aspartate aminotransferase (AST) by colorimetry (Spectrophotometer BTS 315 and kits for dosing CK and AST Biosystem, Spain).

The IJT was conducted on two consecutive days in the morning. Average air temperature and relative humidity (UR) were $23.5^{\circ} \mathrm{C}$ and $73.5 \%$, respectively.

Statistical analysis used randomized block design and the following factors of influence: groups (SP, IP and CG) and times (before, $6 \mathrm{~h}$ and $24 \mathrm{~h}$ after). Analysis of variance (ANOVA) was performed for repeated measurements and the post hoc Holm-Sidak test was used to detect significant differences at significance level of $5 \%(p<0.05)$. The analyses were performed by specific software Minitab 14 and Sigmaplot 11 (MINITAB, 2004; SIGMAPLOT, 2008).

\section{RESULTS AND DISCUSSION}

The serum activity of CK enzyme increased after 6 hours and displayed a tendency to return to initial values 24 hours after the exercise $(p<0,001)$; while the values were not significantly different between SP and IP groups $(\mathrm{p}=$ 0,381). Enzyme activity of the control group behaved similarly to the horses that did the exercise test $(p<0,001)$; moreover, there was no difference between the horses that did and did not do the exercise test $(p=0,642)$. These results are shown in Table 1 and Figure 2.

Activity of AST enzyme was not significantly different either over time ( $\mathrm{p}=0,452)$ or between groups $(\mathrm{p}=$ $0,583)$; however, there was difference between the horses that did the exercise test (SP and IP) and the ones that did not $(\mathrm{CG})$ at all times $(\mathrm{p}=0,007)$, as it can be seen in Table 1 and Figure 3.

Table 1. Plasma activity of creatine kinase (CK) and aspartate aminotransferase (AST) of Brazilian Sport horses submitted or not to incremental jump test (IJT) after muscle biopsy

\begin{tabular}{lccccc}
\hline \multirow{2}{*}{ Activity } & \multicolumn{2}{c}{ Group } & \multirow{2}{*}{ Before } & \multicolumn{2}{c}{ After } \\
\cline { 5 - 6 } & Biopsy & SP $(\mathrm{n}=8)$ & $320.7 \mathrm{a} \pm 71.7$ & $501.4 \mathrm{~b} \pm 156.4$ & $390.7 \mathrm{c} \pm 88.7$ \\
CK & + IJT & IP $(\mathrm{n}=8)$ & $268.4 \mathrm{a} \pm 97.8$ & $517.0 \mathrm{~b} \pm 109.4$ & $412.4 \mathrm{c} \pm 128.5$ \\
& Biopsy & CG $(\mathrm{n}=5)$ & $199.8 \mathrm{a} \pm 28.4$ & $581.2 \mathrm{~b} \pm 156.9$ & $380.2 \mathrm{c} \pm 168.4$ \\
\hline \multirow{2}{*}{ AST } & Biopsy & SP $(\mathrm{n}=8)$ & $388.7^{*} \pm 100.2$ & $324.8^{*} \pm 46.0$ & $334.3^{*} \pm 20.6$ \\
& + IJT & IP $(\mathrm{n}=8)$ & $412.8^{*} \pm 89.6$ & $362.2^{*} \pm 96.5$ & $334.3^{*} \pm 30.7$ \\
& Biopsy & CG $(\mathrm{n}=5)$ & $273.6 \pm 57.6$ & $297.6 \pm 44.0$ & $287.6 \pm 48.8$ \\
\hline
\end{tabular}

Means followed by different letters are significantly different over time. Means followed by asterisk are different from control group. SP $=$ superior performance group, IP = inferior performance group, $\mathrm{CG}=$ control group. 


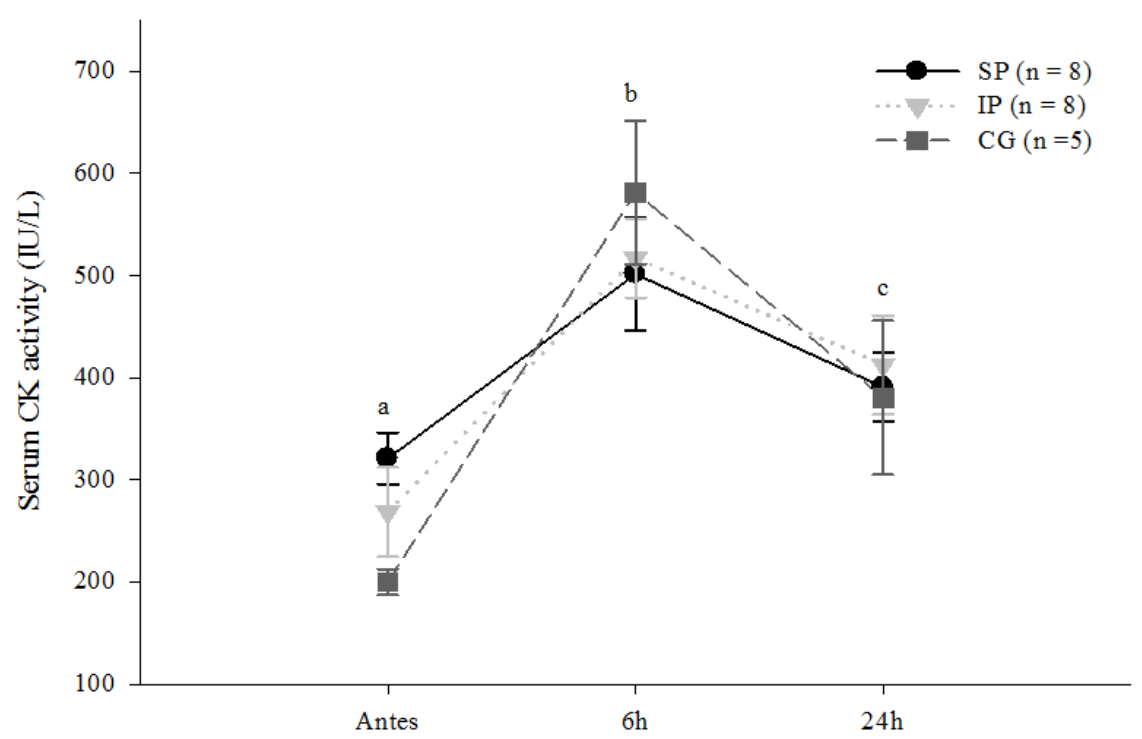

Figure 2. Serum activity of the creatine kinase (CK) enzyme of Brazilian Sport horses submitted or not to the incremental jump test (IJT) and muscle biopsy. SP and IP = groups with superior and inferior performance, respectively, both underwent exercise test and biopsy; $\mathrm{CG}=$ control group, submitted to muscle biopsy only. Different letters above the bars mean significant difference between times

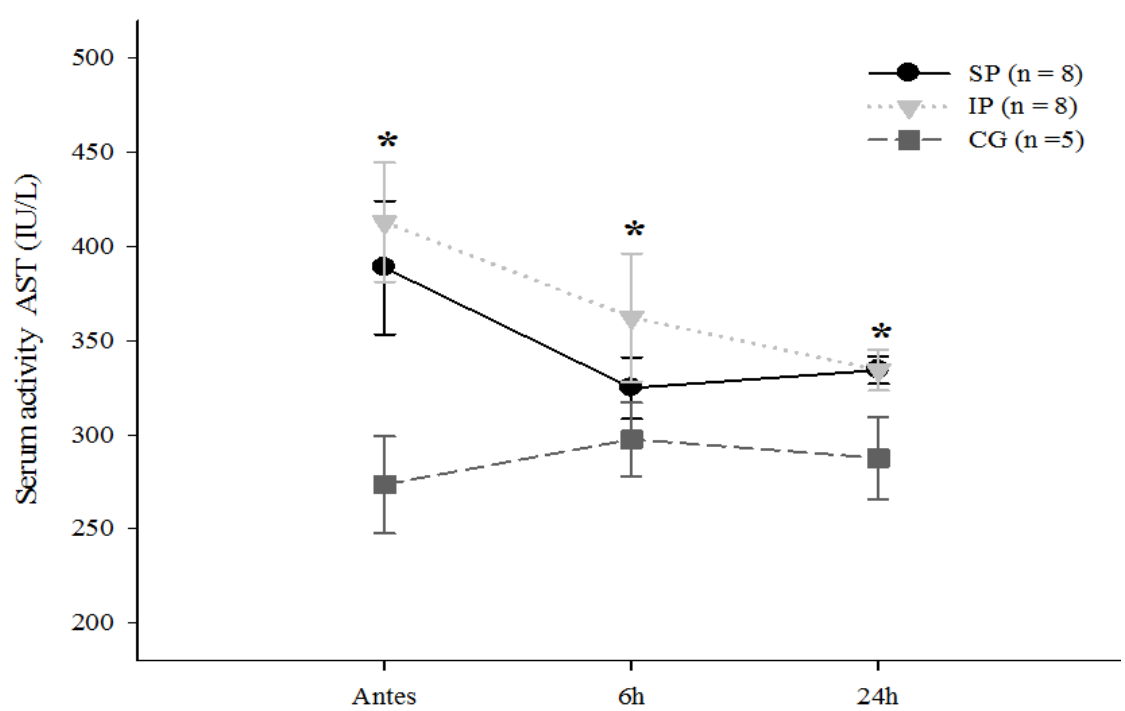

Figure 3. Serum activity of the aspartate aminotransferase (AST) enzyme of Brazilian Sport horses submitted or not to the incremental jump test (IJT) and muscle biopsy. SP and $\mathrm{IP}=$ groups with superior and inferior performance, respectively, both underwent exercise test and biopsy; $\mathrm{CG}=$ control group, submitted to muscle biopsy only. Asterisks above the bars mean significant difference between times 
The baseline values of serum activities of CK and AST enzymes reported in the literature vary considerably, and the values found in this work are slightly higher than the values reported by Boffi et al. (2007) and considerably higher than those reported by Benesi et al. (2009) for two year old Brazilian Sport horses. Age and type of daily exercise influence baseline values of $\mathrm{CK}$ and AST activities (SILVA et al., 2007; BENESI et al., 2009; MUÑOZ et al., 2012) and could explain the differences found in this work.

The two groups that performed the exercise test displayed increased values of CK similar to control group, which did not perform the exercise test, showing that the likely increase in serum activity of this enzyme was due to muscle damage caused by the biopsy and not by the exercise test.

There is no report in the literature regarding muscle injury caused by the biopsy in horses and its relationship with enzyme serum activity. Nevertheless, based on the present study, this injury could be characterized as a small extent injury, since $\mathrm{CK}$ values reached $600 \mathrm{UI} / 1$, far removed from the values reported for extensive injuries caused by myopathies, from 1500 to $10000 \mathrm{UI} / 1$ (BOFFI, 2007).

Art et al. (1990) and Lekeux et al. (1991) reported increased serum activities of CK and AST after a jumping competition. Dias et al (2009), while studying Brazilian Sport horses, also reported increased $\mathrm{CK}$ and AST activity resulting from show jumping, which was not observed in this work for horses that performed the incremental jump test. This difference could be attributed to the height of the obstacles that the horses had to jump, higher than in the present study, thus characterizing higher intensity exercise.
Vincze et al. (2000) reported values of 211-243UI/1 and 275-317UI/1 for CK and AST activities, respectively, for horses soon after a show jumping competition, lower than the values observed in the present study. The same authors point out that the values of these enzyme activities have high individual variability, which somehow limits comparison between different studies.

Kingston (2008) reported that the nature, intensity and duration of exercise influence the increase of serum activity of CK and AST enzymes, and while several studies indicate a significant increase of these activities after high-intensity exercise, some authors report no change after either light or heavy exercise (MACLEAY, 2009). The findings of this study corroborate these reports.

The difference of AST serum activity between horses that performed the exercise (SP and IP groups) and horses from the $C G$ may be explained by individual variation among horses in the groups, since the difference already existed before the exercise and remained unchanged afterwards. Large individual variation for this variable has been reported in the literature (ART et al., 1990)

Few authors have established a relationship between $\mathrm{CK}$ and AST serum activities and performance. Muñoz et al. (2002) reported that training slows down the increase of enzyme activity resulting from exercise. In this study, there was no difference between the CK and AST serum activities for the groups of different performances, possibly due to the low intensity of the exercise test.

Fazio et al. (2011) while working with Thoroughbred racing and trotters reported that training increases the baseline values of serum activity of CK and AST enzymes and attributed this 
increase to changes in myocyte cell permeability associated with anaerobic metabolism response to the training stimulus. The results of this study do not support those findings for jump horses, since serum activities of CK and AST remained the same for groups with distinct performance history, SP and IP. This could be explained to some extent by the large difference in training protocols to which were submitted the horses compared in the study, turf racing and trotting horses in the aforementioned study, and show jumping horses of this work.

From the results presented, it is possible to conclude that the muscle biopsy characterized enough stimulus to cause cell leakage of $\mathrm{CK}$ enzyme and the consequent increase of serum activity. On the other hand, the incremental jump test performed by the horses did not lead to increased serum activity of either CK or AST, and may be considered safe for not causing major cell injury in the muscle involved.

\section{ACKNOWLEDGMENTS}

Thanks are due to the Academia Militar das Agulhas Negras and to the Brazilian Army, especially the Veterinary Hospital for their cooperation with the horses, facilities and personnel. Also to the Fundação de Amparo à Pesquisa do Estado de São Paulo (FAPESP 2011/11080-0) for the financial support.

\section{REFERENCES}

ART, T.; AMORY, H.; DESMECHT, D.; LEKEUX, P. Effect of show jumping on heart rate, blood lactate and other plasma biochemical values.

Equine Veterinary Journal

Supplement, n.9, p.78-82, 1990.
BENESI, F.J.; HOWARD, D.L.; LEAL, M.L.R.; GACEK, F.; SOUZA, J.A.T.; FERNANDES, W.R. Perfil bioquímico de algumas enzimas no plasma sangüíneo de potras da raça Brasileiro de Hipismo $(\mathrm{BH})$ criadas em Colina, Estado de São Paulo. Brazilian Journal of Veterinary Research and Animal Science, v.46, n.4, p.288-295, 2009.

BOFFI, F.M. Patologias que afectan el rendimento desportivo. Transtornos musculares. In: BOFFI, F.M. Fisiologia Del Ejercicio em Equinos. Buenos Aires: Inter-Médica Editorial, 2007. p. $145-151$.

SILVA, I.AC. e; DIAS R.V.C.; SOTOBLANCO, B. Determinação das atividades séricas de creatina quinase, lactato desidrogenase e aspartato aminotransferase em equinos de diferentes categorias de atividade. Arquivo Brasileiro de Medicina Veterinária e Zootecnia, v.59, n.1, p.250-252, 2007.

\section{CONFEDERAÇÃO BRASILERA DE} HIPISMO - CBH. Regulamento de salto CBH. Rio de Janeiro, 2012. 68p.

D'ANGELIS, F.H.; FERRAZ, G.C.; BOLELI, I.C.; LACERDA-NETO, J.C.; QUEIROZ-NETO, A. Aerobic training, but not creatine supplementation, alters the gluteus medius muscle. Journal of Animal Science, v.83, n.3, p.579-585, 2007.

D'ANGELIS, F.H.; SILVA, M.A.G.; MARTINS, C.B.; FERRAZ, G.C.; OLIVEIRA, J.A.; BOLELI, I.C.; LACERDA-NETO, J.C.; QUEIROZNETO, A. Light exercise causes adaptive changes in muscles of young Brasileiro de Hipismo horses. Ciência Rural, v.38, n.5, p.1313 -1318, 2008. 
DIAS, D.C.R.; ROCHA, J.S.; GUSMÃO, A.L.; EL-BACHÁ, R.S.; AYRES, M.C.C. Efeito da suplementação com vitamina e selênio sobre o quadro hematológico, enzimas marcadoras de lesão muscular e índice de peroxidação de biomoléculas em equinos submetidos à atividade de salto. Ciência Animal Brasileira, v.10, n.3, p.790-801, 2009.

FAZIO, F.; ASSENZA, A.; TOSTO, F.; CASELLA, S.; PICCIONE, G.; CAOLA, $\mathrm{G}$. Training and haematochemical profile in Thoroughbreds and Standardbreds: A longitudinal study. Livestock Science, v.141, p.221-226, 2011.

FERRAZ, G.C.; SOARES, O.A.B.; FOZ, N.S.B.; PEREIRA, M.C.; QUEIROZ-NETO, A. The workload and plasma ion concentration in a training match session of high-goal (elite) polo ponies. Equine Veterinary Journal, v.42, n.38, p.191-195, 2010.

KINGSTON, J.K. Hematologic and serum biochemical response to exercise and training. In: HINCHCLIFF, K.W.; KANEPS, A.J.; GEOR, R.J.W.B (Eds.). Equine Exercise Physiology. Saunders, Londres: Elsevier Health Sciences, 2008. 463p.

LEKEUX, P.; ART, T.; LINDEN, A.; DESMECHT, D.; AMORY, H. Heart rate, hematological and serum biochemical responses to show jumping. In: PERSSON, S.G.B.; LINDHOLM, A.; JEFFCOTT, L.B. (Eds.). Equine Exercise Physiology. 1991. p.385-390.

MACLEAY, J.M.. Diseases of the musculoskeletal system. In: REED, S.M.; BAYLY W.M.; SELLON, D.C. (Eds). Equine internal medicine. Philadelphia: Saunders Company, 2009. p.461-531.
MINITAB. Release 14 for Windows ${ }^{\circledR}$. Pennsylvania, USA: Minitab Inc., 2004.

MUÑOZ, A.; RIBER, C.; SANTISTEBAN, R.; LUCAS, R.G.; CASTEJÒN, F M. Effect of training duration and exercise on blood-borne substrates, plasma lactate and enzyme concentrations in Andalusian, AngloArabian and Arabian breeds. Equine Exercise Physiology 6, Equine Veterinary Journal Supplement, v.34, p.245-251, 2002.

MUÑOZ, A.; RIBER, C.; TRIGO, P.; CASTEJÓN, F. Age- and gender-related variations in hematology, clinical biochemistry, and hormones in Spanish fillies and colts. Research in Veterinary Science, v.93, n.2, p.943-949, 2012.

OVERGAARD, K.; FREDSTED, A.; HYLDAL, A.; INGEMANN-HANSEN, T.; GISSEL, H.; CLAUSEN, T. Effects of running distance and training on $\mathrm{Ca} 2+$ content and damage in human muscle.

Medicine and Science in Sports and Exercise, v.36, p.821 - 829, 2004.

SIGMAPLOT. SigmaPlot ${ }^{\circledR}$. Version 11. California, USA: Systat Software Inc, 2008.

TEIXEIRA-NETO, A.R.; FERRAZ, G.C.; MOSCARDINI, A.R.C.; BALSAMÃO, G.M.; SOUZA, J.C.F.; QUEIROZ-NETO, A. Alterations in muscular enzymes of horses competing long-distance endurance rides under tropical climate. Arquivo Brasileiro de Medicina Veterinária e Zootecnia, v.60, n.3, p.543-549, 2008.

TRIGO, P.; CASTEJON, F.; RIBER, C.; MUÑOZ, A. Use of biochemical parameters to predict metabolic elimination in endurance rides. Equine Veterinary Journal Supplement, v.38, p.142-146, 2010. 
Rev. Bras. Saúde Prod. Anim., Salvador, v.14, n.2, p.299-307 abr./jun., 2013 http://www.rbspa.ufba.br ISSN 15199940

VINCZE, A.; SZABÓ, C.; HEVESI, Á.; VERES, S.; ÜTÓ, D.; BABINSZKY, L. Effect of age and event on post exercise values of blood biochemical parameters in show jumping horses. Acta Agraria Kaposváriensis, v.14, n.2, p.185-191, 2010.

Data de recebimento: $15 / 10 / 2012$

Data de aprovação: 18/06/2013 